\title{
THE EFFECT OF HERRINGBONE TECHNIQUE ON STUDENTS' READING COMPREHENSION OF THE FIRST YEAR STUDENTS AT SMP NEGERI 23 MAKASSAR
}

\author{
Bustang \\ STIKES YAPIKA of Makassar \\ eng_bustang@yahoo.co.id
}

\begin{abstract}
The aim of his research is that want to know the herringbone technique application is effective to improve student skill in reading, predict, make the conclusion in every paragraph and able to solve the problem of students in understand reading text or discourse. This research is experimental research and conducted at SMP Negeri 23 Makassar. The total of population in Grade VII students are 480 students that shared in 12 classes. The researcher choose sample in class VII-12 are 32 students. The aim of the researcher to choose class VIIII as a subject of the research because the average of the student in this class is stillless to understand the reading text. The result of data analysis in pre-test and post-test showed that t-test score is 36.25 and t-table score is 2.036. The t-test score is better than t-table or (tt36.25> 2.036). It showed that the students' skill to understand reading text at the end of the research is improved. It can be identified with the significant different between average score in pre-test (3) and post-test 5.8). This research showed that the herringbone technique had tried at the SMP Negeri 23 Makassar and it worked. It appeared that student's English skill in understanding reading text from bad to be better.
\end{abstract}

Keywords: herringbone technique, reading comprehension, experimental research, effectiveness

\section{INTRODUCTION}

Nowadays, the progress of knowledge, science and technology required us to absorb information. Information is merely the most important aspect of our life. Book, magazine, newspaper, bulletin, internet are sources of information we can get if only through reading. Thus, we must read thousands of text to avoid ourselves from out of date.

Teaching reading to students requires many different techniques to avoid boredom and invite students' interest. All techniques, which have been studied earlier such as scanning technique, skimming technique and detailed reading, none is referred as the most effective one. Each of the technique has 
uniqueness and features, which may ease the students in preparing or making their reading tasks (Sangkala, I., \& ul Haq, M. 2014)

Today, there a lot of information, people should know, and they should find many kinds of information sources that are written in English. Thus, to get information, people should read many kinds of information. Reading is a source of getting information. No one can get much information without reading. Actually, Reading is the easiest and the cheapest way to get information, because it can help to know the simple information to the more complex one. In addition, the main important thing that the readers should have the ability to comprehend what they have read.

Reading is one of the most important skills we need in increasing our personal welfare and social progress. It is cannot be denied that language is an integral part of human life and society. It is used to communicate to express argument or opinion to one another. Without language we cannot develop our education, society tradition and culture, spread global information etc.

Shortly, we cannot do anything without using the language. (Rani,2003:4).In our education system, especially in English teaching. Has made the mastery of all language skills. English as an international language in Indonesia is the first foreign language thought from elementary school up to university. This proves that English subject is important for the Indonesia students.

In teaching English as foreign language, it is necessary to note that there are four skills to be mastered which cover reading, speaking, listening and writing. Among the four skills, reading gets greater attention to analyze than other. As De Boer (1992: 16) states thatone of the best important ways of learning however is through reading, success in school and in life depends in large part on your ability read. In general, people intend to be able to read and understand English text because many scientific books are written in English. However, until now, most of the students still encounter difficulties in reading.

This problem is faced by many lecturers and students who are not fluent in English. One of the difficulties encountered by the students is how to remember 
what they have read. Itis important to realize that the teacher need to vary reading rate according to our intention in reading and the students cannot find main idea what they after read.

Using Herringbone technique is one of important technique to make the reading comprehensionare effective. Some method have used in teaching learning process of teaching English, but sometime the methods do not develop thestudents' knowledge. Therefore the writer wants to use this technique to improve the students reading comprehension, especially of the first year student at SMP Negeri 23 Makassar.

In writer point of view, one of the easiest strategies in improving student reading comprehension is herringbone pattern, because it is a very simple instruction that can ease student to comprehend a reading passage as well as finding the main idea.

\section{METHOD}

This research used pre-experimental method with one group pre - test and post-test design. Before giving treatment, the students are given a pre -test. At the end of treatment, the groups of experiment are given the post-test. The design illustrateds follows :

\begin{tabular}{|l|l|l|}
\hline Pre-test & Treatment & Post-test \\
\hline $\mathrm{X} 1$ & 0 & $\mathrm{X} 2$ \\
\hline
\end{tabular}

$\begin{array}{lll}\text { Notes } & : \text { Pre-test } & =\mathrm{X} 1 \\ & : \text { Treatment } & =0 \\ & : \text { Post-test } & =\mathrm{X} 2\end{array}$

(Gay, 2006: 225)

The independent variable is the used of herringbone technique in teaching reading comprehension and Dependent variable of this research is increasing the students' reading comprehension. The population of this research is the fourth semester of English Education Department of Universitas " 45 " Makassar in academic year 2014/2015. The number of population is 80 students from two 
classes. The sample of this research consisted of 15 students in A class of the fourth semester of English Education Department of Universitas "45" Makassar. The instrument of this research is reading comprehension test. In this test, the writer request students to answer some question. Here, the writer used multiple choice tests which consist of 20 questions.

\section{FINDING AND DISCUSSION}

Table 1. Students' Score and Classification in Pre-Test

\begin{tabular}{|c|c|c|c|}
\hline No & Initial of Students & Score & Classification \\
\hline (1) & (2) & (3) & (4) \\
\hline 1 & $\mathrm{AR}$ & 3.5 & Poor \\
\hline 2 & IS & 3.5 & Poor \\
\hline 3 & SN & 2 & Very Poor \\
\hline 4 & $\mathrm{SH}$ & 2 & Very Poor \\
\hline 5 & $\mathrm{~A}$ & 3 & Poor \\
\hline 6 & $\mathrm{MN}$ & 2 & Very Poor \\
\hline 7 & NA & 2 & Very Poor \\
\hline 8 & SA & 2 & Very Poor \\
\hline 9 & MA & 2 & Very Poor \\
\hline 10 & $\mathrm{DN}$ & 3 & Poor \\
\hline 11 & TF & 2 & Very Poor \\
\hline 12 & $\mathrm{AN}$ & 4 & Poor \\
\hline 13 & AZN & 2.5 & Very Poor \\
\hline 14 & $\mathrm{MD}$ & 2.5 & Very Poor \\
\hline 15 & ND & 4.5 & Poor \\
\hline 16 & PN & 2 & Very Poor \\
\hline 17 & $\mathrm{AQ}$ & 2.5 & Very Poor \\
\hline 18 & A & 3 & Poor \\
\hline 19 & TP & 3 & Poor \\
\hline 20 & $\mathrm{NF}$ & 3 & Poor \\
\hline 21 & MR & 2 & Very Poor \\
\hline 22 & $\mathrm{~W}$ & 5.5 & Good \\
\hline 23 & $\mathrm{AA}$ & 2 & Very Poor \\
\hline 24 & MS & 2.5 & Very Poor \\
\hline 25 & A & 4 & Poor \\
\hline 26 & DT & 5.5 & Good \\
\hline 27 & RA & 2 & Very Poor \\
\hline 28 & MP & 4 & Poor \\
\hline 29 & $\mathrm{D}$ & 4 & Poor \\
\hline 30 & $\mathrm{~K}$ & 2 & Very Poor \\
\hline 31 & $\mathrm{~N}$ & 4 & Poor \\
\hline 32 & $\mathrm{R}$ & 4 & Poor \\
\hline \multicolumn{2}{|r|}{ Total } & 95.5 & \\
\hline \multicolumn{2}{|r|}{ Mean Score } & 3 & Poor \\
\hline
\end{tabular}

Source : SMP Negeri 23 Makassar 
Table 2. Students' Score and Classification in Post- Test

\begin{tabular}{|c|c|c|c|}
\hline No & Initial of Students & Score & Classification \\
\hline (1) & (2) & (3) & (4) \\
\hline 1 & AR & 7 & Very Good \\
\hline 2 & IS & 7 & Very Good \\
\hline 3 & $\mathrm{SN}$ & 5.5 & Good \\
\hline 4 & $\mathrm{SH}$ & 5 & Good \\
\hline 5 & $\mathrm{~A}$ & 6.5 & Good \\
\hline 6 & $\mathrm{MN}$ & 4.5 & Poor \\
\hline 7 & NA & 5 & Good \\
\hline 8 & SA & 4.5 & Poor \\
\hline 9 & MA & 4.5 & Poor \\
\hline 10 & $\mathrm{DN}$ & 6 & Good \\
\hline 11 & $\mathrm{TF}$ & 5 & Good \\
\hline 12 & AN & 7.5 & Very Good \\
\hline 13 & AN & 5 & Good \\
\hline 14 & MD & 5 & Good \\
\hline 15 & ND & 8 & Very Good \\
\hline 16 & $\mathrm{PN}$ & 4 & Poor \\
\hline 17 & $\mathrm{AQ}$ & 5.5 & Good \\
\hline 18 & $\mathrm{~A}$ & 5.5 & Good \\
\hline 19 & $\mathrm{TP}$ & 6 & Good \\
\hline 20 & NF & 5.5 & Good \\
\hline 21 & MR & 4.5 & Poor \\
\hline 22 & $\mathrm{~W}$ & 8 & Very Good \\
\hline 23 & AA & 4 & Poor \\
\hline 24 & MS & 5 & Good \\
\hline 25 & $\mathrm{~A}$ & 7 & Very Good \\
\hline 26 & DT & 8.5 & Very Good \\
\hline 27 & RA & 4 & Poor \\
\hline 28 & MP & 7 & Very Good \\
\hline 29 & $\mathrm{D}$ & 7.5 & Very Good \\
\hline 30 & $\mathrm{~K}$ & 5 & Good \\
\hline 31 & $\mathrm{~N}$ & 7 & Very Good \\
\hline 32 & $\mathrm{R}$ & 6.5 & Good \\
\hline \multicolumn{2}{|r|}{ Total } & 186.5 & \\
\hline & Mean Score & 5.8 & Good \\
\hline
\end{tabular}

Source : SMP Negeri 23 Makassar 
Table 3. The t-test Value in Students' Reading Comprehension before and after Treatment

\begin{tabular}{|c|c|c|c|}
\hline $\mathrm{t}-$ test & $\mathrm{t}$-table & Comprehension & Different \\
\hline $\mathbf{3 6 . 2 5}$ & $\mathbf{2 . 0 3 6}$ & t-test $>\mathrm{t}$-table & Significant \\
\hline
\end{tabular}

Based on the table 3 after the writer calculated all scores used t-test formula the result of t-test value students' reading comprehension before and after giving treatment in reading test indicated that the t-test value of reading were greater than t-table value (tt $36.25>$ th2.036). This finding used to determine the hypothesis that occurred in this research as it stated that null hypothesis (Ho) is rejected when the value of t-test was greater than the value of t-test, and alternative hypothesis (H1) was accepted. It means that, in this research, automatically the alternative hypothesis (H1) was accepted and the null hypothesis (Ho) was rejected. Based on the table 3above there was a significant result between $\mathrm{t}-$ table and $\mathrm{t}$-test after applied herringbone technique at SMP Negeri 23 Makassar.

\section{CONCLUSION}

Based on the findings, the writer also concluded that the using of herringbone technique in teaching and learning process at SMP Negeri23Makassar could achieved the students competence in learning English especially in reading subject. Besides that, after they joined the class where the herringbone technique was applied the students also more active to follow the class because this method made the students more interest to learn by adding their vocabulary, share their opinion in group and thought the students using "wh" question in order to comprehend the reading test as well as they can get more comprehensible input after the meeting. At the end of the meeting (post - test), most of the students can increase their achievement not only about their vocabulary but also how to answer question much more better than before. 
In addition, the writer found that there was a significant difference result of students was 2.036( $\mathrm{t}$ - test ) and the level of significance was 36.25. It means that (H0) was rejected and alternative hypothesis ( $\mathrm{H} 1$ ) was accepted. In other word, herringbone technique could improve the students' reading comprehension at SMPN 23 Makassar.

\section{REFERENCES}

Abidin, Zainal. 2006. The Effectiveness of SAVI (Somatic, Auditory, Visuaal, and Intellectual) As a Reading Method. Thesis S1 FKIP Unismuh Makassar. Unpublished.

Anderson, Jonathan; et. all. 1999. Efficient Reading : A Practical Guide. Sidney: Mc. Graw. Hill.

Brown, H. Douglas. 2004. Language Assessment Principles and Classroom Practices. Longman : Cambridge University Press.

Chow, C.Y. and Vohr, J.H. 1995. Characteristics of Herringbone-Grooved, Gaslubricated Journal Bearings. ASME Journal of Basic Engineering.

Cunningham, R.E., Fleming, D.P. Anderson, W.J. 1999. Experimental Stability Studies of the Herringbone-Grooved Gas-Lubricated Journal Bearing. ASME Journal of Lubrication Technology.

De Boer, John. 1992. Basic Language, New York : Philadelphia Cambridge.

Edward, H. and Jones Jr; 1997. Short Stories, Chicago : Elcamino Collage

Gay, L. R., E., Millis.and Peter Arasian. 2006. Educational Research: Competencies for Analysis and Application ,. New jersey: Prentice Hall.

Hendra. 2007. Improving Students Reading Comprehension by Using Herringbone Pattern. State University of Makassar. Unpublished.

Herber, H. L. 1998. Teaching Reading in the Content Areas (2 ${ }^{\text {nd }}$ ed). Englewood Clifs, NJ : Prentice Hall.

Hornby, J.B, 2000. Oxford Advanced Learner's Dictionary. ( $2^{\text {nd }}$ Ed). New York: Oxford University Press. 
Sangkala, I., \& ul Haq, M. (2014). Wondershare quiz creator software improves students' reading comprehension. JKIP, 1(2), 128-135. Retrieved from https://ojs.fkip.unismuh.ac.id/index.php/jkip/article/view/41

Lutfiah, 2008. Improving Reading Comprehension by Using Authentic Material. Makassar: Thesis. FKIP Unismuh. Unpublished.

Munawwarah, Emba. 2007. The Application of Suggestopedia Methode in Improving the Reading Comprehension of the Second Year Students of MA Madani Alauddin Pao Pao. Thesis UIN Alauddin Makassar. Unpublished.

Mardiana. 2005. The Reading Achievement of the second year student of SMPN 6 Rangas Majene By using Imaginative Reading Materials. A Thesis English Education of Tarbiyah Faculty of UIN Alauddin Makassar. Unpublished.

Nurmala, Lia. 2008. Improving The Students Vocabulary Achievement Through The Use of STAD Method. Thesis SI FKIP Unismuh Makassar. Unpublished.

Rahmadani, Nur. 2007. Improving English Students Achievement Through Cooperative Learning at The First Year Students of SMAN 2 Sungguminasa. Thesis S1 FKIP Unismuh Makassar. Unpublished.

Rani, Nur Aisyah. 2003. The Correlation Between Reading Speed and Comprehension of the Sixth Semester Students of English Department of Tarbiyah Faculty at IAIN Alauddin Makassar. Unpublished.

Smith and Robinson. 1998. Making the Most of Your Text Book. England : Longman Group. Ltd.

Steele, Khatie. 2004. The Herringbone Technique National College of Explanation.

Sudjana. 2008. Metode Statistika. Bandung : PT. Gramedia. 